\title{
Parent-to-offspring transfer of sublethal effects of copper exposure: Metabolic rate and life-history traits of Daphnia
}

\author{
Transferencia paterno-filial de efectos subletales de la exposición al cobre: Tasa \\ metabólica y rasgos de historia de vida en Daphnia
}

\author{
MAURICIO A. FERNÁNDEZ-GONZÁLEZ ${ }^{1}$, JAVIER GONZÁLEZ-BARRIENTOS ${ }^{1}$, MAURICIO J. CARTER ${ }^{1,2}$ \& \\ RODRIGO RAMOS-JILIBERTO1, * \\ ${ }^{1}$ Centro Nacional del Medio Ambiente, Fundación de la Universidad de Chile, Av. Larraín 9975, La Reina, Santiago, Chile \\ ${ }^{2}$ Department of Animal and Plant Sciences, University of Sheffield, Western Bank, Sheffield, UK \\ *Corresponding author: rodrigo.ramos@cenma.cl
}

\begin{abstract}
In ecological communities, pollution driven perturbations exert immediate effects on sensitive individuals, but these effects may be transmitted among interacting organisms and spread over the community through several paths. This makes the assessment and prediction of ecological consequences of pollution difficult. The propagation of perturbation effects among organisms can be horizontal among organisms that coexist in space and time, and vertical among organism that belong to different generations. The latter process is poorly understood, in particular in planktonic organisms facing metal pollution. In this study we evaluate the vertical transfer of effects driven by sublethal copper stress on the heartbeat rate, somatic growth and fertility of Daphnia pulex. In order to evaluate this, we performed a factorial experiment in which parental and filial generations were exposed to both copperenriched and control media. We found that parental exposure to copper exerted a significant effect on the heartbeat rate, somatic growth and fertility of offspring, revealing a transgenerational effect in $D$. pulex. This response may be explained by a higher resource investment on repair/detoxification processes in the parental generation, allocating fewer resources to offspring quality. Our results suggest that responsiveness of organisms to stress is dependent on parental history.
\end{abstract}

Key words: ecotoxicology, heartbeat rate, maternal effects, transgenerational effects, zooplankton.

\section{RESUMEN}

En las comunidades ecológicas, las perturbaciones producidas por los contaminantes ejercen efectos inmediatos en los individuos sensibles, pero estos efectos podrían ser transmitidos entre los organismos interactuantes y extenderse sobre la comunidad a través de múltiples vías. Esto hace difícil la evaluación y predicción de las consecuencias ecológicas de la contaminación. La propagación de los efectos de una perturbación entre los organismos puede ser horizontal, entre organismos que coexisten espacial y temporalmente, y vertical, entre organismos que pertenecen a generaciones diferentes. Este último proceso ha sido escasamente entendido, en particular en organismos planctónicos enfrentados a contaminación por metales. En este estudio evaluamos la transferencia vertical de los efectos producidos por un estrés subletal de cobre sobre la tasa de latidos cardiacos, el crecimiento corporal y la fertilidad de Daphnia pulex. Para evaluar esto, se realizó un experimento factorial en el cual las generaciones parental y filial fueron expuestas tanto a medios enriquecidos con cobre como a medios control. Encontramos que la exposición de las madres al cobre ejerció un efecto significativo en la tasa de latidos cardiacos, el crecimiento corporal y la fertilidad de la descendencia, revelando un efecto transgeneracional en $D$. pulex. Esta respuesta puede explicarse por una mayor inversión de recursos en los procesos de reparación/ desintoxicación en la generación parental, asignando menos recursos a la calidad de su descendencia. Nuestros resultados sugieren que la reactividad de los organismos al estrés depende de la historia parental.

Palabras clave: ecotoxicología, efectos maternos, efectos transgeneracionales, tasa de latidos cardiacos, zooplancton.

\section{INTRODUCTION}

The study of effects of metal pollution on aquatic biota has attracted significant attention in the last decades since many industrial processes have contributed to this source of disruption in freshwaters (Dolédec \& Statzner 2010), a resource that is being depleted at an accelerating rate worldwide. Metal exposure is known to exert a diverse array of harmful effects on aquatic organisms. In invertebrates, examples include oxidative stress (Barata et al. 
2005), elevated oxygen consumption (Gerhardt 1995), lowered feeding rate (Blockwell et al. 1998), altered locomotion (Untersteiner et al. 2003) and decreased individual growth rate (Winner 1985). Nevertheless, understanding and predicting the ecological consequences of anthropogenic disturbances and pollutants in particular on natural ecosystems is difficult, since the immediate effects of perturbations on sensitive individuals may be transmitted among interacting organisms and spread through the community via multiple pathways.

Borrowing the concept from genetics, two sources of ecological transfer of effects among organisms can be distinguished. Horizontal transfer of effects takes place among organisms that coexist in a given time and place and whose biological performance depends on each other. For example, an herbicide could impair reproduction of plants but indirectly lead to decreasing abundances of herbivores whose resources were depleted (e.g., Lampert et al. 1989, Juttner et al. 1995, Kasai \& Hanazato 1995), and ultimately decrease the abundance of carnivore predators that depend on herbivores (Rhor et al. 2006). Horizontal transfer leads to what is customarily known as indirect effects (Wootton 1994). Vertical transfer, on the other hand, refers to propagation of effects within an ecosystem among organism that belong to different generations. For example, organisms could express a response to a contaminant to which only their parents were exposed. This kind of phenomenon is usually known as maternal effects (Bernardo 1996), transgenerational effects (Marshall 2008), latency (Brock et al. 2008) or delayed effects (Beckerman et al. 2002). Both horizontal and vertical transfer of effects among organisms constitute two main sources of ecological complexity whose insufficient comprehension has hampered our advancement in the assessment of environmental risk associated to actual or potential human-driven perturbations.

Although there is an increasing interest of scientists in studying horizontal transfer of pollutant effects in ecological communities (Clements \& Rohr 2009), less attention has been paid to the study of vertical transfer, which has been evaluated in only a few taxa and mainly considering their consequences on organisms' life-histories (Hammers-Wirtz \&
Ratte 2000, Lin et al. 2000, Marshall 2008, Kwok et al. 2009). However, although lifehistory traits are related directly to fitness, they are prone to be constrained by trade-offs among them. Therefore, characterizing life history and physiological parameters allows one to better capture the range of potential effects of perturbations. Consequently, in this study we evaluate the vertical transfer of effects driven by sublethal copper stress on the metabolic rate (measured as heartbeat rate), somatic growth and fertility of Daphnia pulex (Leydig 1860). This herbivore species is a cosmopolitan inhabitant of ponds and lakes and constitutes an important link in aquatic food webs, transferring energy from producers towards large predatory species. In addition, daphnids are efficient controllers of algal biomass and bacterial growth. Hence, the biological activity of Daphnia exerts a strong influence on community dynamics, lake metabolism and ultimately the generation of ecosystem services (Edmonson \& Litt 1982; Lampert et al. 1986). In copper-exposed daphnids, metabolic rate (and hence heartbeat rate) is expected to increase due to a higher energetic demand driven by induced biochemical and physiological mechanisms of resistance. As a consequence of a higher allocation of resources to maintenance mechanisms, growth, development and reproduction rates are expected to be lowered (Jager et al. 2006). If vertical transfer does not take place, these effects are expected to be independent of the parental environment.

\section{METHODS}

\section{Daphnia cultures}

Stock cultures of Daphnia pulex were obtained from Bagshaw pond, England (53 $20^{\circ} 5.37^{\prime \prime}$ N, $1^{\circ} 27^{\prime} 8.12$ ” W) We used this strain because we had several English clones genotypified for future comparative analyses. Nevertheless, after this study all individuals coming from cultures of English strains were destroyed. Twenty females were kept in the laboratory in individual $50 \mathrm{~mL}$ vials with $40 \mathrm{~mL}$ of hard water (ASTM 1980), under 14:10 D:L photoperiod, temperature of 20 $\pm 2{ }^{\circ} \mathrm{C}$, and $\mathrm{pH} 7.8 \pm 0.2$. The cladocerans were fed with Chlorella vulgaris at a density of $10^{6}$ cells $\mathrm{mL}^{-1}$.

Prior to conducting the experiment, we determined the sensitivity of $D$. pulex to copper using an acute bioassay to estimate the LC50 (modified from EPA 1993). The nominal copper concentrations used to perform the bioassay were $25,50,75,100$ and 
$125 \mu \mathrm{g} \mathrm{L}^{-1} \mathrm{Cu}^{+2}$. The test medium was supplemented with Chlorella vulgaris $10^{6}$ cells $\mathrm{mL}^{-1}$ and enriched with $2.5 \mathrm{~mL} \mathrm{~L}^{-1}$ of nutritional supplement Phyllum (Hayashi et al. 2008) in order to replicate the experimental conditions to be used later.

\section{Experimental setup}

Twenty neonates $(<24 \mathrm{~h})$ were placed individually into $50 \mathrm{~mL}$ vials with $40 \mathrm{~mL}$ of medium without copper (control medium). From their third brood we took 40 neonates. Twenty of them were placed individually into $50 \mathrm{~mL}$ vials with $40 \mathrm{~mL}$ of control medium. The remaining 20 neonates were placed individually into 50 $\mathrm{mL}$ vials containing $40 \mathrm{~mL}$ of $20 \mu \mathrm{g} \mathrm{L}^{-1} \mathrm{Cu}^{+2}$. All media were renewed every 24 hours, until day 12 when animals released their third clutch. These animals constitute the parental generation $\mathrm{F} 0$.

From the third brood of each of the parental groups (F0), we took 50 randomly chosen neonates (F1). Twenty-five of the F1 daughters coming from the parental control group (C group) were placed individually into vials with $40 \mathrm{~mL}$ of control medium (C-C group). The other 25 coming from the parental control group were individually exposed to $20 \mu \mathrm{g} \mathrm{L}^{-1}$ $\mathrm{Cu}^{+2}$ (C-Cu group). Experimental media were renewed every 24 hours, until the third day. The same procedure was performed with the $\mathrm{F} 1$ individuals whose mothers were exposed to copper, obtaining in this way the treatments $\mathrm{Cu}-\mathrm{C}$ and $\mathrm{Cu}-\mathrm{Cu}$. This design corresponds to a balanced $2 \times 2$ full factorial design with parental environment (with and without copper) and filial environment (with and without copper) as experimental factors.

\section{Size-specific heartbeat rate}

We estimated the heartbeat rate ( $\left.\mathrm{HB} \mathrm{min}^{-1}\right)$ of $D$. pulex, corrected by individual body mass in $\mathrm{mg}$. For calculating body mass, measured body length was transformed to mass following a standard empirical regression for Daphnia (Bottrell et al. 1976). For measuring the heartbeat rate we impeded locomotion of the experimental organisms by means of the following treatment. We first placed each individual on a slide using a Pasteur pipette. Then the surrounding water was removed. Using a dissecting needle, each individual was attached by its helmet to a line of vaseline disposed on the slide and medium was added immediately. This step took less than $10 \mathrm{sec}$. By this procedure, the abdomen kept free thus allowing easy access of water to the gills. Five individuals were disposed on each slide, separated $1 \mathrm{~cm}$ from each other. Finally, the slide was placed in a petri dish filled with 70 $\mathrm{mL}$ of hard water (ASTM 1980), at a temperature of $20 \pm$ $2{ }^{\circ} \mathrm{C}, \mathrm{pH} 7.8 \pm 0.2$ and constant diffuse light. Measurements of individuals' heartbeat rate were made at the third day from birth, on digital videos $(3 \times 10$ seconds) recorded with a digital camera attached to a microscope. For assessing the acclimation time needed prior to the measurements, we observed the variation of heartbeat rate of single individuals through reading that parameter every 30 minutes, over a period of 14 hours from the mounting procedure.

\section{Life-history traits}

We examined shifts in somatic growth and fertility caused by copper exposure. For analyzing somatic growth we measured the body length of the F1 individuals at the beginning of the experiment (neonates) and then at the end of experiment (3-day old). Length measurements were made using digital images obtained from a digital camera attached in a microscope focused (top down) on the slide, keeping individuals at the same focal point. The precision of the length measurements was $10^{-4} \mathrm{~mm}$. For fertility data, we inspected all individuals every day and annotated the clutch size at first reproduction.

\section{Statistics}

Data were analyzed by means of two-way randomization ANOVA (1500 randomizations over the original values), for testing the effects of parental and filial environments and their interaction on size-specific heartbeat rate, somatic growth and fertility. All analyses were done with the package RT2.1. For technical details about the randomization procedures the interested reader could see the accompanying text (Manly 1997).

\section{RESULTS}

\section{Copper tolerance and acclimation time}

The acute bioassay resulted in an LC50 value of $60 \mu \mathrm{g} \mathrm{L}^{-1}$. This means that $24 \mathrm{~h}$ copper exposure at a concentration of $60 \mu \mathrm{g} \mathrm{L}^{-1}$ caused mortality of $50 \%$ of experimental Daphnia. Following Koivisto et al. (1995) we decided to use $1 / 3$ of the LC50 value $\left(20 \mu \mathrm{g} \mathrm{L}^{-1}\right)$ for all subsequent experiments.

The heartbeat rate of a few tested individuals stabilized after 10 hours from the mounting procedure. Based on this result, we set the acclimation time for all measurements of heartbeat rate to be 12 hours.

\section{Size-specific heartbeat rate}

Both parental and filial environments, as well as their interaction, exerted a significant effect (Table 1) on the heartbeat rate of Daphnia. The observed differences were mainly driven by the high heartbeat rate resulting from the $\mathrm{Cu}-\mathrm{Cu}$ treatment (Fig. 1A).

\section{Life history traits}

Neonates of F1 with different parental environments did not differ significantly in their body lengths. Therefore, final body length became a direct measurement of somatic growth. Both environments as well as their interaction exerted a significant effect on final body length (Table 1). The differences in body 
sizes were mainly due to a reduced body length of organisms in the $\mathrm{Cu}-\mathrm{Cu}$ treatment (Fig. 1B).

Clutch size (Fig. 1C) also responded significantly to both parental and filial environments, but their interaction was not significant (Table 1). This means that copper exposure decreased fertility of organisms that were directly exposed to the stressor and that of organisms whose mother had been exposed, in an additive way (Table 1). Throughout our experiments, no mortality occurred in any treatment.

\section{DISCUSSION}

Our results revealed a transgenerational effect of copper exposure across generations in Daphnia. In particular, we observed that individuals whose mothers were exposed to copper showed a significant increase in heartbeat rate and a decrease of somatic growth rate when they also developed under a polluted environment, as compared to individuals whose mothers were not exposed to the pollutant. Similarly, fertility was decreased by copper exposure in $\mathrm{F} 0$ and $\mathrm{F} 1$, but the interaction of both environments was not significant.

The transgenerational responses observed in our experiments may be explained by a higher resource investment in detoxification processes in the parental generation, allocating fewer resources to offspring quality (see Sibly 1996, Kooijman et al. 2009). Consequently, exposed daughters had a higher expenditure on repair/detoxification processes and poorer energy allocation to somatic and reproductive investment. Increased energy demand by detoxification/ repair processes may be attributable to the synthesis of defense proteins (Cousins 1985, Smith et al. 2001, Kil et al. 2006, Rose et al. 2006, Wu et al. 2006), and specifically, increased synthesis of metallothionein, which is considered to be a highly energy-demanding process under sublethal metal exposure in daphniids (Barber et al. 1990). Also, copper could produce lipid peroxidation, which has been shown to increase the levels of glutathione peroxidase in Daphnia (Barata et al. 2005). Consequently, the observed decrease in somatic growth and reproduction is

\section{TABLE 1}

Summary of two-way randomized ANOVA for the three response variables: fertility, body growth and heartbeat rate. The two factors were the environment (with or without copper) of the parental (F0) and filial (F1) generations.

Resumen de ANDEVA de dos vías por aleatorizaciones para las tres variables respuesta: fertilidad, crecimiento corporal y tasa de latidos cardiacos. Los dos factores fueron el ambiente (con y sin cobre) de la generación parental (F0) y filial (F1).

\begin{tabular}{|c|c|c|c|c|c|}
\hline & $\mathrm{DF}$ & SS & MS & $\mathrm{F}$ & $\mathrm{P}$ \\
\hline \multicolumn{6}{|l|}{ Fertility } \\
\hline F0 environment & 1 & 210.20 & 210.20 & 26.2 & $<0.0001$ \\
\hline F1 environment & 1 & 106.10 & 106.10 & 13.13 & 0.0005 \\
\hline Interaction & 1 & 16.81 & 16.81 & 2.08 & 0.1525 \\
\hline Error & 96 & 775.60 & 8.08 & & \\
\hline \multicolumn{6}{|l|}{ Body growth } \\
\hline F0 environment & 1 & 0.89 & 0.89 & 22.86 & $<0.0001$ \\
\hline F1 environment & 1 & 0.43 & 0.43 & 10.96 & 0.0014 \\
\hline Interaction & 1 & 0.37 & 0.37 & 9.53 & 0.0027 \\
\hline Error & 88 & 3.44 & 0.04 & & \\
\hline \multicolumn{6}{|c|}{ Size-specific heartbeat rate } \\
\hline F0 environment & 1 & 451.00 & 451.00 & 19.5 & $<0.0001$ \\
\hline F1 environment & 1 & 503.30 & 503.30 & 21.76 & $<0.0001$ \\
\hline Interaction & 1 & 430.70 & 430.70 & 18.62 & $<0.0001$ \\
\hline Error & 52 & 1203.00 & 23.13 & & \\
\hline
\end{tabular}


consistent with higher resource allocation to maintenance (Baillieul et al. 2005, Zeman et al. 2008, Massarin et al. 2010). Elevation of metabolic rate, measured as oxygen consumption, driven by exposure to metal ions is a common phenomenon, which has been reported for both invertebrates (Thurberg et al. 1974, Knop et al. 2001, Vosloo et al. 2002) and vertebrates (Rowe et al. 1998, Hopkins et al. 1999, Tatara et al. 2001). An alternative hypothesis that is consistent with our experimental findings is that $\mathrm{Cu}$ itself could be transferred to offspring (Zhao et al. 2009), causing some degree of physiological stress on daughters. This may account for the slight reductions in the offspring that were not subjected to the second round of $\mathrm{Cu}$ exposure, and the significant reductions in the offspring that were subjected to $\mathrm{Cu}$. In this case, vertical transfer of effects could be caused by vertical transfer of the metal itself, an hypothesis considered by Lin et al. (2000).

Transgenerational pollutant effects have been reported for wide range of taxa (Lin et al. 2000, Hopkins et al. 2006, Marshall 2008, Ho \& Burggren 2010). In Daphnia, previous work presented cases where vertical transfer of adverse effects led to reduced offspring fitness by affecting some life-history traits. This has been reported for metal pollutants such as cadmium (Guan \& Wang 2006) and uranium (Massarin et al. 2010), as well as for other stressors such as UV radiation (Huebner et al. 2009).

It has become clear that parent-to-offspring transfer of effects is not rare in nature (Beckerman et al. 2002), but its consequences on population and community dynamics remains a topic requiring further advances. With regard to vertical transfer of effects driven by pollutant exposure, our results indicate that responsiveness to stress of organisms' traits is strongly dependent on parental history. Therefore, the appropriate assessment of ecological risk associated with toxic substances released to the environment by industrial activities could be seriously flawed if they were based on immediate effects only. More realistic toxicity tests performed on successive generations could provide valuable information about the actual threat associated to a given stressor on wild species, and constitute a more sensitive probe for

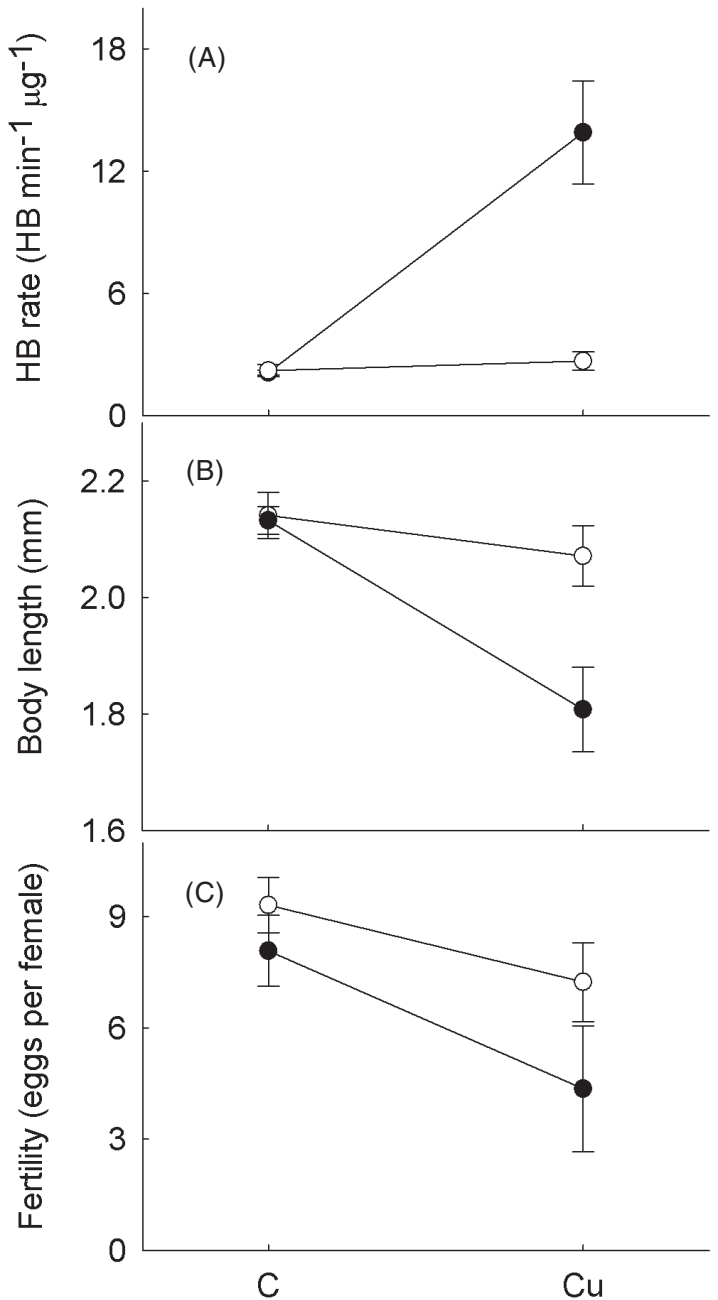

F1 Enviroment

Fig. 1: Size-specific heartbeat rate (A), juvenile body length (B) and fertility (C) of Daphnia pulex as a function of parental and filial exposure to copper. Means $\pm 95 \%$ confidence intervals are shown. Closed and open circles show results for organisms whose mothers (F0) were exposed and not exposed to copper, respectively. Filial (F1) environment is displayed on the x-axis. C: control medium, $\mathrm{Cu}$ : copper-added medium.

Tasa tamaño-específica de latidos cardiacos (A), longitud corporal juvenil (B) y fertilidad (C) de Daphnia pulex en función de la exposición parental y filial al cobre. Se muestran valores promedio \pm intervalos de confianza de $95 \%$. Círculos negros y blancos muestran resultados para organismos cuyas madres (F0) fueron expuestas y no expuestas al cobre, respectivamente. El ambiente filial (F1) se muestra sobre la abscisa. C: medio control, $\mathrm{Cu}$ : medio con adición de cobre. 
measuring ecosystem health.

Open questions to be addressed in the future include elucidating whether parental exposure to a given stressor could alter offspring tolerance to other substances, and evaluating potential interactions among multiple stressors that give rise to shifts in offspring trait values. On the other hand, the integration of vertical and horizontal routes for the transfer of pollutant effects among organisms may reveal new mechanisms behind community disruption and promote the generation of new ecological knowledge for the understanding of threatened ecosystems and hopefully for the development of more effective and enduring management actions.

ACKNOWLEDGEMENTS: The authors thank A. P. Beckerman for kindly providing the Daphnia strain used in this study and for stimulating discussions. This study was partially supported by grant FONDECYT $1090132 / 2009$ to R.R.-J

\section{LITERATURE CITED}

ASTM (1980) Standard practice for conducting acute toxicity tests with fishes, macroinvertebrates and amphibians. ASTM standard: E729-80. Philadelphia.

BAILLIEUL M, R SMOLDERS \& R BLUST (2005) The effect of environmental stress on absolute and mass-specific scope for growth in Daphnia magna Strauss. Comparative Biochemistry and Physiology, Part C 140: 364-373.

BARBER I, DJ BAIRD \& P CALOW (1990) Clonal variation in general responses of Daphnia magna Straus to toxic stress. II. Physiological effects. Functional Ecology 4: 409-414.

BARATA C, I VARO, JC NAVARRO, S ARUN \& C PORTE (2005) Antioxidant enzyme activities and lipid peroxidation in the freshwater cladoceran Daphnia magna exposed to redox cycling compounds. Comparative Biochemistry and Physiology, Part C 140: 175-186.

BECKERMAN AP, TG BENTON, E RANTA, V KAITALA \& P LUNDBERG (2002) Population dynamic consequences of delayed life-history effect. Trends in Ecology \& Evolution 17: 263-269.

BERNARDO J (1996) Maternal effects in animal ecology. American Zoologist 36: 83-105.

BLOCKWELL SJ, EJ TAYLOR, I JONES \& D PASCOE (1998) The influence of fresh water pollutants and interactions with Asellus aquaticus (L.) on the feeding activity of Gammarus pulex. Archives of Environmental Contamination and Toxicology 34: $41-47$

BOTTRELL HH, A DUNCAN, ZM GLIWICZ, E GRYGIEREK, A HERZIG, A HILLBRICHTILKOWSKA, H KURASAWA, P LARSSON \& T WEGLENSKA (1976) A review of some problems in zooplankton production studies. Norwegian Journal of Zoology 24: 419-456.

BROCK TCM, KR SOLOMON, RPA VAN
WIJNGAARDEN \& L MALTBY (2008) Temporal extrapolation in ecological effect assessment of chemicals. In: Solomon KR, TCM Brock, D de Zwart, SD Dyer, L Posthuma, SM Richards, H Sanderson, PK Sibley \& PJ van den Brink (eds) Extrapolation practice for ecological effect characterization of chemicals: 187-221. CRC/ Taylor and Francis/SETAC Press, Pensacola, FL, USA.

CLEMENTS WH \& JR ROHR (2009) Community responses to contaminants: Using basic ecological principles to predict ecotoxicological effects. Environmental Toxicology and Chemistry 28: 1789-1800.

COUSINS RJ (1985) Absorption, transport, and hepatic metabolism of copper and zinc: Special reference to metallothioneins and ceruloplasmin. Physiological Reviews 65: 238-309.

DOLÉDEC S \& B STATZNER (2010) Responses of freshwater biota to human disturbances: Contribution of J-NABS to developments in ecological integrity assessments. Journal of the North American Benthological Society 29: 286311.

EDMONDSON W \& A LITT (1982) Daphnia in Lake Washington. Limnology and Oceanography 27: 272-293.

EPA (1993) Methods for measuring the acute toxicity of effluents and receiving waters to freshwater and marine organisms. Fourth Edition, EPA/ 600/4-90/02TF.

GERHARDT A (1995) Monitoring behavioural responses to metals in Gammarus pulex (L) (Crustacea) with impedance conversion. Environmental Science and Pollution Research 2: $15-23$.

GUAN R \& WX WANG (2006) Comparison between two clones of Daphnia magna: Effects of multigenerational cadmium exposure on toxicity, individual fitness, and biokinetics. Aquatic Toxicology 76: 217-229.

HAMMERS-WIRTZ M \& HT RATTE (2000) Offspring fitness in Daphnia: Is the Daphnia reproduction test appropriate for extrapolating effects on the population level? Environmental Toxicology and Chemistry 19: 1856-1866.

HAYASHI Y, LH HECKMANN, A CALLAGHAN \& RM SIBLY (2008) Reproduction recovery of crustacean Daphnia magna after chronic exposure to ibuprofen. Ecotoxicology 17: 246-251.

HO DH \& WW BURGGREN (2010) Epigenetics and transgenerational transfer: A physiological perspective. The Journal of Experimental Biology 213: 3-16.

HOPKINS WA, S DURANT, B STAUB, C ROWE \& B JACKSON (2006) Reproduction, embryonic development, and maternal transfer of contaminants in an amphibian Gastrophryne carolinensis. Environmental Health Perspectives 114: 661-666.

HOPKINS WA, CL ROWE \& JD CONGDON (1999) Elevated maintenance costs in banded water snakes, Nerodia fasciata, exposed to coal combustion wastes. Environmental Toxicology and Chemistry 18: 1258-1263.

HUEBNER JD, NL LOADMAN, MD WIEGAND, DLW YOUNG \& LA WARSZYCKI (2009) The effect of chronic exposure to artificial UV-B radiation on the survival and reproduction of Daphnia magna across two generations, Photochemistry and 
Photobiology 85: 374-378.

JAGER T, EHW HEUGENS \& SALM KOOIJMAN (2006) Making sense of ecotoxicological test results: Towards application of process-based models. Ecotoxicology 15: 305-314.

JUTTNER I, A PEITHER, JP LAY, A KETTRUP \& SJ ORMEROD (1995) An outdoor mesocosm study to assess ecotoxicological effects of atrazine on a natural plankton community. Archives of Environmental Contamination and Toxicology 29: 435-441.

KASAI F \& T HANAZATO (1995) Effects of the triazine herbicide, simetryn on freshwater plankton communities in experimental ponds. Environmental Pollution 89: 197-202.

KIL IS, SW SHIN, HS YEO, YS LEE \& JW PARK (2006) Mitochondrial NADP+-dependent isocitrate dehydrogenase protects cadmium-induced apoptosis. Molecular Pharmacology 70: 10531061.

KNOP M, R ALTENBURGER \& H SEGNER (2001) Alterations of physiological energetics, growth and reproduction of Daphnia magna under toxicant stress. Aquatic Toxicology 53: 79-90.

KOIVISTO S, M KETOLA \& M WALLS (1995) Effects of copper on life-history traits of Daphnia pulex and Bosmina longirostris. Aquatic Toxicology 32: 255-269.

KOOIJMAN SALM, J BAAS, M BONTJE, M BROERSE, C VAN GESTEL \& T JAGER (2009) Ecotoxicological applications of dynamic energy budget theory. In: Devillers J (ed) Ecotoxicology modeling: 237-259. New York, USA.

KWOK KWH, EPM GRIST EPM \& KMY LEUNG (2009) Acclimation effect and fitness cost of copper resistance in the marine copepod Tigriopus japonicus. Ecotoxicology and Environmental Safety 72: 358-364

LAMPERT W, W FLECKNER, E POTT, U SCHOBER \& KU STORKEL (1989) Herbicide effects on planktonic systems of different complexity. Hydrobiologia 188/189: 415-424.

LAMPERT W, W FLECKNER, H RAI \& B TAYLOR (1986) Phytoplankton control by grazing zooplankton: a study on the spring clear-water phase. Limnology Oceanography 31: 478-490.

LIN H, S HSU \& P HWANG (2000) Maternal transfer of cadmium tolerance in larval Oreochromis mossambicus. Journal of Fish Biology 57: 239-249.

MANLY BF (1997) Randomization, bootstrap and Monte Carlo methods in biology. London, Chapman and Hall.

MARSHALL DJ (2008) Transgenerational plasticity in the sea: Context-dependent maternal effects across the life history. Ecology 89: 418-427.

MASSARIN S, F ALONZO, L GARCÍA-SÁNCHEZ, R GILBIN, J GARNIER-LAPLACE \& JC POGGIALE (2010) Effects of chronic uranium exposure on life history and physiology of Daphnia magna over three successive generations. Aquatic Toxicology 99: 309-319.

ROHR JR, JL KERBY \& A SIH (2006) Community ecology as a framework for predicting contaminant effects. Trends in Ecology \& Evolution 21: 606-613.

ROSE WL, RM NISBET, PG GREEN, S NORRIS, T FAN, EH SMITH, GN CHERR \& SL ANDERSON
(2006) Using an integrated approach to link biomarker responses and physiological stress to growth impairment of cadmium-exposed larval topsmelt. Aquatic Toxicology 80: 298-308.

ROWE CL, OM KINNEY, RD NAGLE \& JD CONGDON (1998) Elevated maintenance costs in an anuran (Rana catesbeiana) exposed to a mixture of trace elements during the embryonic and early larval periods. Physiolgical Zoology 71: 27-35.

SMITH RW, SC BLANEY, K DOWLING, A STURM, M JONSSON \& DF HOULIHAN (2001) Protein synthesis costs could account for the tissuespecific effects of sub-lethal copper on protein synthesis in rainbowtrout (Oncorhynchus mykiss). Aquatic Toxicology 53: 265-277.

SIBLY RM (1996) Effects of pollutants on individual life histories and population growth rates. In: Newman M \& C Jagoe (eds) Ecotoxicology: A hierarchical treatment: 197-223. CRC Press, Boca Raton, Florida.

TATARA CP, MC NEWMAN \& M MULVEY (2001) Effect of mercury and GPI-2 genotype on standard metabolic rate of eastern mosquitofish (Gambusia holbrooki). Environmental Toxicology and Chemistry 20: 782-786.

THURBERG FP, A CALABRESE \& MA DAWSON (1974) Effects of silver on oxygen consumption in bivalves at various salinities. In: Vernberg FJ \& WB Vernberg (eds) Pollution and physiology of marine organisms: 67-78. Academic Press, New York.

UNTERSTEINER H, J KAHAPKA \& H KAISER (2003) Behavioural response of the cladoceran Daphnia magna Straus to sublethal copper stress validation by image analysis. Aquatic Toxicology 65: 435-442.

VOSLOO A, WJ VAN AARDT \& LJ MIENIE (2002) Sublethal effects of copper on the freshwater crab Potamonautes warreni. Comparative Biochemistry and Physiology - Part A: Molecular \& Integrative Physiology 133: 695-702.

WINNER RW (1985) Bioaccumulation and toxicity of copper as affected by interactions between humic acid and water hardness. Water Research 19: 449-455.

WOOTTON JT (1994) The nature and consequences of indirect effects in ecological communities. Annual Review of Ecology and Systematics 25: 443-466.

WU SM, MJ SHIH \& YC HO (2006) Toxicological stress response and cadmium distribution in hybrid tilapia (Oreochromis sp.) upon cadmium exposure. Comparative Biochemistry and Physiology, Part C 145: 218-226.

ZEMAN F, R GILBIN, F ALONZO, C LECOMTEPRADINES, J GARNIER-LAPLACE \& C ALIAUME (2008) Effects of waterborne uranium on survival, growth, reproduction and physiological processes of the freshwater cladoceran Daphnia magna. Aquatic toxicology 86: 370-378.

ZHAO CM, WH FAN \& WX WANG (2009) Aqueous and dietary copper uptake and elimination in Daphnia magna determined by the ${ }^{67} \mathrm{CU}$ radiotracer. Environmental toxicology and chemistry 28: 2360-2366. 
